\title{
The mechanism for ensuring a balanced model of local self-government as a necessary condition for municipal development
}

\author{
Elena Georgievna Konysheva* \\ Prosecutor's Office of the Pervomaisky District of the Altai Territory, Novoaltaisk, Russia
}

\begin{abstract}
The purpose of the study is the development of theoretical recommendations for a new concept of municipal power and local selfgovernment in the Russian Federation. The objectives of the study are to consider the relationship of the legal foundations of local self-government with the historical forms of local self-government and government, and to study the comparative legal characteristics of conceptual approaches to foreign and domestic models of local self-government. The methodological basis of the research includes analysis, synthesis, induction, deduction, generalization, concrete historical, comparative legal, formal legal and statistical methods. Within the framework of the study, attention is focused on the recently published works of Russian and foreign scientists, statistical data are provided. According to the results of the study, modern organizational models of local self-government are formed with consideration to the needs of multi-level public administration, which presupposes the functional involvement of local self-government bodies in the state executive power system and their responsibility for the implementation of public powers. The scientific novelty of the study lies in obtaining theoretical conclusions that a necessary condition for further municipal development in Russia is the creation of an effective mechanism for reconciling the interests of local communities with state interests, the absence of which leads to an excessive strengthening of state or social principles and a violation of a balanced model of local self-government.

Keywords: local government, municipal government, balance of interests
\end{abstract}

\section{Introduction}

Difficulties in implementing the constitutional principles of local self-government require to re-examine the choice of the optimal model of local self-government, based on the existing experience of legal regulation, current trends and problems of multi-level public administration. Moreover, one of the basic principles of local self-government, the principle of subsidiarity in particular, has not been reflected in Russian legislation. In general terms, the content of the principle of subsidiarity reduces to the fact that the exercise of public powers should be entrusted to the authorities closest to the population, take into account the real possibilities for their implementation and allow the central government to intervene in

* Corresponding author: helen155@yandex.ru 
governance at a lower level only in case of improper exercise of powers based on the requirements proportionality and adequacy

The change in state policy in the field of local self-government determines the scientific interest in the study of the doctrinal, legal and empirical foundations of the constitutional and legal structure of Russia.

In this regard, the works of Babichev and Smirnov [1], Babun [2], Bondar and Dzhagaryan [3], Vasilyev, Leksin [4], Nevinsky [5], Nekrasov [6], Peshin [7], Khabrieva and Klishas [8], Cherkasov [9] and other researchers, whose long-term scientific studies make it possible to give an objective assessment of current developments.

It should be noted that the works of foreign authors, in particular, Berg, Rao, Kemp, are in demand within the framework of a comparative study of Russian and foreign models of local self-government.

At the same time, a critical analysis of the updated constitutional model of local selfgovernment from the standpoint of a practice-oriented approach, taking into account the originality of Russia and the peculiarities of its historical and cultural heritage, acquires special relevance.

According to the hypothesis put forward by the author, modern organizational models of local self-government are built taking into account the needs of multi-level public administration, which presupposes the functional involvement of local self-government bodies in the state executive power system and their responsibility for the implementation of public powers (on the principle of subsidiarity or on the principle of verticalization of power), and a necessary condition the provision of an effective mechanism for reconciling the interests of local communities with state interests, the absence of which leads to an excessive strengthening of state or social principles and a violation of the balanced model.

\section{Methods}

The main methods aimed at solving these problems are both general scientific methods of cognition - analysis, synthesis, induction, deduction, generalization, and specific scientific methods - concrete historical, comparative legal, formal legal, statistical.

\section{Results and discussion}

The results of the study show that Russia has got the experience of local self-government and the functioning of local government bodies in terms of decentralized and centralized government with the traditions of a community-based structure. Community traditions were widely used in the public interest [10].

Strengthening the centralization of public administration mainly pursued political goals and reduced the self-government potential of Russian society, but contributed to the strengthening of the rule of law and the mobilization of resources [6]. It can be concluded that the ideology of communal interests, with its characteristic institution of mutual responsibility, received its interpretation in the ideology of a strong paternalistic state.

The current model of local self-government is based on the Constitution of the Russian Federation of December 12, 1993, in accordance with which local self-government is recognized as one of the foundations of the constitutional system and is guaranteed by the state by consolidating the principles of independence within its own powers and organizational independence from the system of state authorities (Article 12) with the attribution of issues of legal regulation in the field of local self-government to the joint jurisdiction of the Federation and its subjects (clause "n", part 1 of article 72). 
In the context of a strengthened political and legal system and the absence of the threat of a return of "legal separatism", the powers of the constituent entities of the Russian Federation have expanded in establishing the procedure for the formation, powers, term of office, accountability, accountability of local self-government bodies and on other issues of their organization and activities, followed by a strengthening of the position of executive the administrative body of local self-government [1].

Although, when the Constitution was adopted, local self-government bodies were not named by public authorities, the systemic interpretation of constitutional norms made it possible to develop an official position on classifying local self-government as one of the types of public power based on the general principle of democracy (Article 3), which is taken into account in the text of the Constitution in an edition of March 14, 2020 (Part 3, Article 132).

The dialectical unity of state power and local self-government creates an integral mechanism of public administration, in which local self-government bodies can be endowed with separate state powers, exercised under the control of the state. Following the laws of dialectics, the interpretation of local self-government is not reduced to a simplified opposition to the state, but is filled with new content, in conjunction with the institutions of the legal status of the individual, civil society and public authority, establishing reasonable limits of state interference in local autonomy [3, 11-13].

The noted global trend is the unification of social and economic goals of organizational and power structures of all levels on the principles of coordination and parity cooperation between different levels of public authority or by concentrating power through the executive branch $[4,14,15]$.

Part 3 of Art. 132 of the Constitution of Russia indicates the criterion of interaction between state and local self-government bodies as "for the most effective solution of problems in the interests of the population living in the corresponding territory".

However, there are no effective mechanisms for the participation of local selfgovernment bodies in the procedure for the transfer of state powers and the redistribution of powers between the levels of state power and local self-government, harmonization of their parameters, which affects the one-sidedness of legal relations in the planning and decisionmaking process affecting the interests of local self-government $[1,16,17]$.

Thus, in order to ensure the unity of the public administration system and the optimal model of local self-government, acceptable for the purposes of municipal development and for solving the problems of the state, within the framework of the dualistic concept of local self-government, a mechanism is required to coordinate the interests of the state and the local community.

In search of an appropriate mechanism, one should not ignore the institution of resolving disagreements between local self-government (government) bodies with the participation of a local state representative (as in tsarist Russia) and a higher state authority (as in the Soviet system), including the principle of democratic centralism, which makes it possible to avoid confrontations at all levels of government, with the priority role of a representative institution endowed with exclusive rule-making powers and directly involved in the formation of the executive body (regarding the federal level of public power, the text of the updated Constitution provides for a procedure for appointing members of the Government of the Russian Federation using parliamentary approval procedures for candidates, which, in addition to ensuring balance of checks and balances increases the transparency and publicity of decision-making, balanced approaches to assessing the professional qualities of candidates [8].

Equally, it would be a mistake to reject positive foreign experience that has similar methodological grounds. For example, the distribution of funds by levels of government in the United States takes place with the participation of the Commission on 
Intergovernmental Relations, which includes an equal number of representatives from the federal government, from state and local governments. The institute of obligatory consultations with local authorities is provided for when adopting decrees of the minister in Great Britain $[2,18]$.

As emphasized in the scientific community, the Russian model of local self-government is the borrowing (reception) of fundamentally different Anglo-Saxon and continental systems of local self-government [7, 12, 19, 20], reflecting the policies of states of the liberal and conservative type [21]. However, recently, there has been a significant rapprochement against the background of the policy of pluralism and the practice of reconciling multidirectional interests $[9,22]$.

Along with this, local self-government is viewed from the point of view of social choice not prepared in the course of the historical process $[5,23]$ and as its own path of development [24].

It is also true that the "import" of legal models without adaptation to national conditions, as well as their strict isolation, is not accompanied by efficiency [12].

Due to problems related to life support in municipalities, the level of public confidence in local authorities does not exceed 33\% [25].

Many people associate local self-government with the joint activities of state authorities and local self-government bodies [26].

The need for state participation and state support is especially acute against the background of a significant dispersal of rural municipalities and depopulation of territories that do not have socio-economic development potential [27].

Despite the widespread acceptance of the dualistic concept [28], the implementation of the institution of local self-government on the verge of restoring the vertical of power raises many concerns in the expert community $[29,30]$.

\section{Conclusion}

Thus, the imperfection of the local self-government model indicates the need for its completion in order to create a legal mechanism that ensures a balance of interests in the public sector, which in turn requires further scientific research and improvement of legislation.

\section{References}

1. I.V. Babichev, B.V. Smirnov, Mestnoe samoupravlenie v sovremennoi Rossii: stanovlenie i razvitie. Istoriko-pravovye aspekty [Local self-government in modern Russia: formation and development. Historical and legal aspects] (Norma: INFRA-M, Moscow, 2014)

2. R.V. Babun, Organizatsiya mestnogo samoupravleniya [Organization of local selfgovernment] (KNORUS, Moscow, 2013)

3. N.P. Bondar, A.A. Dzhagaryan, Constit. and Munic. Law 4, 65 (2016)

4. I.V. Leksin, Territorialnoe ustroistvo Rossii: Konstitutsionno-pravovye problemy [Territorial structure of Russia: Constitutional and legal problems] (LENAND, Moscow, 2014)

5. V. Nevinsky, Izbrannye trudy [Selected Works] (Norma, Moscow, 2021)

6. P.I. Nekrasov, Mestnaya publichnaya vlast v Rossii (monarkhicheskii i sovetskii periody) [Local public authority in Russia (monarchist and Soviet periods)] (GUM, Moscow, 2012) 
7. N.L. Peshin, Local Law, 1, 5 (2019)

8. T.Ya. Khabrieva, A.A. Klishas, Tematicheskii kommentarii k Zakonu Rossiiskoi Federatsii o popravke k Konstitutsii Rossiiskoi Federatsii ot 14 marta 2020 g. № 1FKZ [Thematic commentary on the Law of the Russian Federation on the amendment to the Constitution of the Russian Federation dated March 14, 2020 No. 1-FKZ] (Norma: INFRA-M, Moscow, 2021)

9. A.I. Cherkasov, Munitsipalnoe upravlenie v demokraticheskikh gosudarstvakh: organizatsiya i problemy funktsionirovaniya [Municipal governance in democratic states: organization and functioning problems] (Norma: INFRA-M, Moscow, 2019)

10. E.G. Konysheva, Ob osobennostyakh stanovleniya i razvitiya mestnogo samoupravleniya $v$ Rossii [On the peculiarities of the formation and development of local self-government in Russia], in Constitutional and municipal law. Materials of the section of constitutional and municipal law of the VI International Scientific and Practical Conference "Kutafin Readings" - "Harmonization of the Russian legal system in the context of international integration" (Prospect, Moscow, 2014)

11. P.P. Dureev, Bul. Chelyabinsk State Univ. 33(324), 73-76, (2013)

12. O.A. Akopyan, N.V. Vlasova, P.A. Gracheva, et. al., Pravovye modeli i realnost [Legal models and reality], in Yu.A. Tikhomirov, E.E. Rafalyuk, N.I. Khludenev (eds.) (INFRA-M, Moscow, 2018)

13. V.K. Samigullin, Constit. and Munic. Law 1, 68 (2016)

14. R.L. Kemp, Forms of Local Government: A Handbook on City, County and Regional Options, in N.C. Jefferson (ed.) (2007)

15. Transforming Local Political Leadership, in R. Berg, N. Rao (eds.) (Houndmills, Palgrave Macmillan, 2005)

16. T.M. Byalkina, Constit. and Munic. Law 5, 71-72 (2016)

17. P.G. Soloviev, State Pow. and Loc. Govern. 4, 20 (2016)

18. V.E. Chirkin, Konstitutsiya: rossiiskaya model [Constitution: Russian model] (Jurist, Moscow, 2002)

19. T.A. Zheldybina, Zakonotvorchestvo v Rossii: evolyutsiya i sovremennost [Lawmaking in Russia: Evolution and Modernity] (INFRA-M, Moscow, 2017)

20. Yu.A. Tikhomirov, Deistvie zakona [Operation of the law] (Izvestia, Moscow, 1992)

21. P.P. Dureev, Mestnoe samoupravlenie i ego organy: sotsialno-filosofskii analiz [Local government and its bodies: socio-philosophical analysis] (SSAU, Krasnoyarsk, 2013)

22. T.A. Vasilyeva, N.V. Varlamova (eds.), Instituty publichnoi vlasti v usloviyakh globalizatsii [Institutions of public power in the context of globalization] (Norma: INFRA-M, Moscow, 2020)

23. B.P. Abzeev, Lichnost i gosudarstvo v Rossii: vzaimnaya otvetstvennost $i$ konstitutsionnye obyazannosti [Personality and State in Russia: Mutual Responsibility and Constitutional Obligations] (Norma, Moscow, 2008)

24. T.V. Shatkovskaya, North Caucasian Leg. Bul. 2, 10-14 (2015)

25. Doverie institutam [Trust in institutions]. Accessed on: June 26, 2021. [Online]. Available: https://www.levada.ru/2020/09/21/doverie-institutam/

26. M.P. Shaikhullin, Konstitutsionno-pravovye garantii mestnogo samoupravleniya $v$ Rossiiskoi Federatsii [Constitutional and legal guarantees of local self-government in the Russian Federation] (Jurlitinform, Moscow, 2016) 
27. Chislennost naseleniya / Demografiya [Population / Demography]. Accessed on: June 26, 2021. [Online]. Available:

http://www.gks.ru/wps/wcm/connect/rosstat_main/rosstat/ru/statistics/population/demo graphy/\# (date of retrieval: 20.09.2019

28. E.G. Konysheva, Munic. Service: Legal Iss. 1, 30-32 (2014)

29. E.S. Shugrina (ed.), Doklad o sostoyanii mestnogo samoupravleniya v Rossiiskoi Federatsii: Sovremennye vyzovy i perspektivy razvitiya [Report on the state of local self-government in the Russian Federation: Current challenges and development prospects] (Prospect, Moscow, 2016)

30. A.A. Uvarov, Mestnoe samoupravlenie kak forma publichnoi vlasti naroda v RF [Local self-government as a form of public power of the people in the Russian Federation] (NORMA, Moscow, 2020) 